\title{
Education in Polish and a Level of Higher Education of Polish Minority in Lithuania
}

\begin{abstract}
For centuries there has been Polish-language education in Lithuania which results from the centuries-long presence and tradition of the Polish national minority in this country. Polish education in Lithuania has its successes, but also problems that arise from the political and cultural specificity of the issue. On the one hand, it should be noted that in no other country (except Poland) there are as many state-run schools with Polish language of instruction as in Lithuania, on the other - it must be said that currently Polish-language education in Lithuania has become the source of many tensions in Poland and Lithuania inter-state relations. Polish education in Lithuania was a problem for the communist authorities of Soviet Lithuania, and now - for the authorities of independent Lithuania, which undertake both assimilation and integration activities concerning several thousand students and teachers of these schools. The first part of the article presents the situation of Polish-language education in the period of Soviet Lithuania between 1945 and 1990, marking the desperate struggle of parents and teachers to maintain the Polish language of teaching in these schools. The second chapter analyses the issue during the years of independent Lithuania - between 1990 and 2017, emphasizing the revival of Polish education in 1990-2000 and the persistent pursuit of the Polish minority society in Lithuania of ensuring education in Polish and maintain the existing state. The third chapter examines the indicator of higher education of the Polish minority in Lithuania against a national background, signifying that it was twice lower than the national average throughout the whole period. Moreover, it presents the funding of universities by 'student basket' model and proportion of school graduates with Polish language of instruction in this model and assesses the prospect of solving the problem.
\end{abstract}

1 Faculty of Economics and Informatics in Vilnius, the branch of the University of Białystok in Vilnius, E-MAIL: wolkonowski@uwb.edu.pl. 


\section{Keywords:}

secondary education, Polish national minority, Lithuania, higher education, higher education level.

\section{INTRODUCTION}

A large indigenous Polish minority lives in Lithuania. National population censuses carried out after World War II always recorded a large percentage of Poles living in the Vilnius region - in Vilnius and within a radius of about $100 \mathrm{~km}$ from the city. After the incorporation of the Vilnius region into the Lithuanian Soviet Republic after the Second World War, the Polish minority in Lithuania became the third largest (after the Lithuanians and the Russians) ethnic group in Lithuania. Table 1 presents data on the ethnic composition of Lithuania in the years 1959-2017.

Table 1. Population ( $\mathrm{N}$ in thousands) of Lithuania and ethnic composition (in \% of the total) according to the last 5 censuses

\begin{tabular}{|c|c|c|c|c|c|c|c|c|c|c|c|c|c|c|}
\hline \multirow{2}{*}{$\begin{array}{l}\text { Census } \\
\text { Ethnicity }\end{array}$} & \multicolumn{2}{|c|}{1959} & \multicolumn{2}{|c|}{1970} & \multicolumn{2}{|c|}{1979} & \multicolumn{2}{|c|}{1989} & \multicolumn{2}{|c|}{2001} & \multicolumn{2}{|c|}{2011} & \multicolumn{2}{|c|}{$2017^{*}$} \\
\hline & $\mathrm{N}$ & $\%$ & $\mathrm{~N}$ & $\%$ & $\mathrm{~N}$ & $\%$ & $\mathrm{~N}$ & $\%$ & $\mathrm{~N}$ & $\%$ & $\mathrm{~N}$ & $\%$ & N* & $\%$ \\
\hline Lithu & 2,150 & 79.3 & 2,507 & 80.1 & 2,712 & 30.0 & 2,924 & 79.6 & 907 & 83.4 & 561 & 84.2 & 476 & 86. \\
\hline US & 31 & 85 & 268 & 8.6 & 304 & 90 & 344 & 94 & 22 & 67 & 177 & 58 & 131 & 4.6 \\
\hline oles & 30 & 8.5 & 240 & & 247 & 3 & 258 & 7. & 235 & 6.7 & 200 & 6.6 & 159 & 5.6 \\
\hline elc & 30 & & 45 & & 58 & & 63 & & 43 & & 36 & & 35 & 1. \\
\hline Ukr & 18 & & 25 & & 2 & 0 & 45 & & 22 & 0. & 16 & . & 18 & 0.6 \\
\hline ew & 25 & 0 & 24 & & & & 12 & & & & & & & 0 \\
\hline ther & 27 & 1.0 & 19 & 0.5 & 24 & 0.7 & 29 & 0.8 & 53 & 1.0 & 50 & 1.6 & 27 & 0.9 \\
\hline 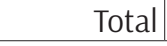 & - & 00 & (1) & & & חم & 675 & 0 & 484 & 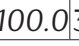 & 043 & 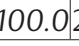 & 348 & 00. \\
\hline
\end{tabular}

* - Resident population at the beginning of the year, preliminary data. Source: (Lietuvos TSR, 1973); (Lietuvos Statistikos, 1990); (Lietuvos Statistikos, 2002); Lithuanian Statistics Department, Resident population at the beginning of the year, https://osp.stat.gov.It/statistiniu-rodikliu-analize\#/ (accessed: November 28, 2017).

A significant number of the Polish minority in the Vilnius region (in particular areas of this region, the Polish population constitutes the majority) shows the Polish character of these lands and Polish tradition. One of its manifestations is Polish education, which has its deep roots and traditions here (Sienkiewicz, 2009). However, during the Second World War (during the German occupation all schools with Polish language of instruction in this region were closed) and repatriation (in 1945-1948 and 1955-1959), the Polish national group in the Vilnius region suffered large losses, both material and spiritual. A significant part of the 
Polish intelligentsia died under German occupation or was deported to Siberia after the Second World War.

\section{POLISH EDUCATION IN LITHUANIA IN THE PERIOD 1945-1989}

Shortly after the liberation of Vilnius in July 1944, a new school year in Lithuania began in October. In the first years of the post-war period, repatriation to Poland took place, during which 197,000 Poles left Lithuania, including 2,120 teachers, over 45,000 white-collar workers, 830 artists and cultural workers, 431 social activists (Srebrakowski, 2002) - the intelligentsia constituted more than 30\% of repatriates. Such a large loss of Polish intelligentsia to the Vilnius region had a negative impact on Polish-language education in Lithuania. The new Lithuanian communist authorities had a vision of their country primarily promoting schools with the Lithuanian language of instruction and sought to eliminate education with the Polish language of instruction and to minimize the number of schools with Russian language of teaching. In the late 1940s, the communist authorities of Lithuania and the Ministry of Education made the decision to transform Polish schools into Lithuanian-language schools, justifying their decision on the grounds that Poles in the Vilnius region were polonized Lithuanians and the presence of Polish schools in Lithuania was a "continuation of the 'polonization policy' carried out by the Polish bourgeois government” (Srebrakowski, 2002; Mikłaszewicz, 2016). However, protests of parents of Polish schoolchildren and complaints to the communist authorities in Vilnius and Moscow caused that, according to the suggestion of the Moscow authorities, on October 1, 1950, it was permitted to open schools with Polish language of instruction and to educate teaching staff for these schools. To this end, it was decided to establish the Teachers' Seminary and the Teachers' Institute, as well as to print textbooks for Polish schools in Lithuania. Such 'generosity' of the Soviet authorities was aimed at strengthening the Russian-language education and leading to the disagreement between both ethnic groups - Poles and Lithuanians, while Polish-language education in the Vilnius region was to play a counterbalance to Lithuanian-language education in this region. Table 2 contains data on the number of pupils in schools in Lithuania with the Lithuanian, Polish and Russian languages of instruction in the period of Soviet Lithuania, and the number of schools and pupils.

After Stalin's death in 1953, the communist authorities of Lithuania, after an unsuccessful attempt to lithuanize Polish education in the late 1940s, intensified actions aimed at transforming schools with the Polish language of instruc- 
Table 2. Number of pupils in schools (with Lithuanian, Polish and Russian languages of instruction) in Lithuania and proportion to the total number of pupils in 1947-1990 as well as the number of schools and pupils

\begin{tabular}{|l|c|c|c|c|c|c|c|c|c|}
\hline \multicolumn{1}{|c|}{ Indicator/Year } & $\begin{array}{c}1947 / \\
48\end{array}$ & $\begin{array}{c}1956 / \\
57\end{array}$ & $\begin{array}{c}1960 / \\
61\end{array}$ & $\begin{array}{c}1965 / \\
66\end{array}$ & $\begin{array}{c}1970 / \\
71\end{array}$ & $\begin{array}{c}1975 / \\
76\end{array}$ & $\begin{array}{c}1978 / \\
79\end{array}$ & $\begin{array}{c}1985 / \\
86\end{array}$ & $\begin{array}{c}1989 / \\
90\end{array}$ \\
\hline $\begin{array}{l}\text { Number of pupils in the } \\
\text { country (thousands) }\end{array}$ & 373.7 & 396.8 & 410.0 & 484.0 & 533.0 & 542.0 & 532.0 & 555.8 & 531.3 \\
\hline $\begin{array}{l}\text { Number of pupils in Lithua- } \\
\text { nian-language schools } \\
\text { (thousands) }\end{array}$ & n.d. & 294.2 & 342.0 & 400.0 & 447.0 & 459.0 & 451.0 & n.d. & 415.9 \\
\hline $\begin{array}{l}\text { Number of pupils in } \\
\text { Polish-language schools } \\
\text { (thousands) }\end{array}$ & 25.5 & 19.6 & 22.0 & 23.0 & 19.0 & 17.0 & 15.0 & n.d. & 10.6 \\
\hline $\begin{array}{l}\text { Number of pupils in } \\
\text { Russian-language schools } \\
\text { (thousands) }\end{array}$ & n.d. & 32.7 & 43.0 & 61.0 & 67.0 & 66.0 & 66.0 & n.d. & 79.6 \\
\hline $\begin{array}{l}\text { Proportion of pupils in } \\
\text { Lithuanian-language } \\
\text { schools (\%) }\end{array}$ & n.d. & 74.2 & 83.41 & 82.64 & 83.86 & 84.69 & 85 & n.d. & 78.3 \\
\hline $\begin{array}{l}\text { Proportion of pupils in } \\
\text { Polish-language schools (\%) }\end{array}$ & $\mathbf{6 . 8}$ & $\mathbf{4 . 9}$ & $\mathbf{5 . 3 7}$ & $\mathbf{4 . 7 5}$ & $\mathbf{3 . 5 6}$ & $\mathbf{3 . 1 4}$ & $\mathbf{2 . 8 2}$ & $\mathbf{n . d .}$ & $\mathbf{2 . 0 0}$ \\
\hline $\begin{array}{l}\text { Proportion of pupils in Rus- } \\
\text { sian-language schools (\%) }\end{array}$ & n.d. & 8.2 & 10.49 & 12.60 & 12.57 & 12.18 & 12.41 & n.d. & 15.0 \\
\hline $\begin{array}{l}\text { Number of Polish-language } \\
\text { schools }\end{array}$ & 220 & 287 & 246 & 210 & n.d. & n.d. & 63 & 48 & 44 \\
\hline $\begin{array}{l}\text { Number of students in the } \\
\text { country }\end{array}$ & n.d. & 15,561 & 26,700 & 46,000 & 57,000 & 63,000 & 69,000 & 65,300 & 69,547 \\
\hline $\begin{array}{l}\text { Number of students of } \\
\text { Polish origin in the country }\end{array}$ & n.d. & 439 & n.d. & 1058 & n.d. & n.d. & 2001 & n.d. & 2469 \\
\hline $\begin{array}{l}\text { Proportion of students of } \\
\text { Polish origin to the total } \\
\text { number of students in } \\
\text { Lithuania (\%) }\end{array}$ & $\mathbf{n . d .}$ & $\mathbf{2 . 8}$ & $\mathbf{n . d .}$ & $\mathbf{2 . 3}$ & $\mathbf{1 . 9}$ & $\mathbf{n . d .}$ & $\mathbf{2 . 9}$ & $\mathbf{n . d .}$ & $\mathbf{3 . 6}$ \\
\hline
\end{tabular}

* - about 50,000 pupils out of the total number were taught in bilingual and trilingual schools in Lithuania. n.d. - no data available. Source: (Lietuvos TSR, 1957); (Lietuvos TSR, 1966); (Lietuvos TSR, 1968); (Lietuvos TSR, 1979); (Lietuvos Statistikos, 1991); (Lietuvos TSR, 1982); (Lietuvos mokymo, 1990).

tion into Russian-language schools. These actions led to significant russification (Mikłaszewicz, 2016) - the number of children in Polish-speaking schools began to decrease, while in Russian-language schools - to grow. The second repatriation of Poles from Lithuania, which took place in 1955-1959, led to another reduction of the Polish national group in Lithuania by another 46.5 thousand of people. 
However, unlike the first repatriation, the professional structure of repatriation to Poland is still unknown today (Srebrakowski, 2002). It is logical to say that it was probably similar to the first repatriation, which meant another significant decrease in the number of the intelligentsia of the Polish minority.

According to the data in Table 2, the number of students in Polish-speaking schools remained at a similar level up to 1965, while in the following years there was a significant decrease and an increase in the number of students in Russianlanguage schools. The intensity of the process of russification is demonstrated by the fact that while the Polish ethnic minority in Lithuania constituted $7 \%$ of the total population in 1989, Polish schools accounted only $2.00 \%$ of all pupils in Lithuania. A separate issue is the disproportionately low percentage of Polish students in Lithuania, which ranged from $1.9 \%$ to $3.6 \%$ (Table 2).

\section{POLISH EDUCATION IN LITHUANIA IN THE PERIOD 1990-2017}

In 1990, after regaining its independence, Lithuania reformed its education - the learning content in secondary and higher education was changed profoundly and the model of secondary and higher education was modified as well. During the first years of independence, Lithuania chose a path of European integration and joining the European Union and NATO. These standards impose compliance with the principles of respect for the rights of national and ethnic minorities at many levels, including education (Kuzborska, 2012, 2013). Table 3 contains data for the period 1990-2017, from which we can see the rebirth of Polish education in Lithuania in the years 1990-2000, when the number of children in schools increased from 10.6 thousand at the beginning of 1990 to 21.8 thousand (over twofold increase) in the 1999/2000 school year, while the number of schools increased from 44 to 73. In the next period, between 2000 and 2017, we can observe a decrease in the number of children in Polish-language education (from 21.8 thousand in 2000 to 11.3 thousand in 2016/17) and a decrease in the number of schools with Polish language of instruction - from 73 to 52 . However, the general drop in the number of pupils in Lithuania should be noted - from 576.1 thousand in 1990/91 to 330.9 thousand in the school year 2016/17, which corresponds to a decrease of $42.56 \%$. The decrease in Polish-language education was from 21.8 thousand in the school year 1999/2000 to 11.3 thousand in 2016/2017, which corresponds to a decrease of $48.17 \%$. Percentage of pupils in Polish-speaking schools dropped from 3.8\% to $3.4 \%$ in this period and remained at this level during the period between 2014 and 2017. Table 3 shows a huge drop in the number of pupils of Russian-language 
Table 3. Number of pupils in schools (with Lithuanian, Polish and Russian languages of instruction) in Lithuania and proportion to the total number of pupils in 1990-2017 as well as the number of schools and pupils

\begin{tabular}{|c|c|c|c|c|c|c|c|c|c|}
\hline Indicator/Year & $\begin{array}{c}1990 / \\
91\end{array}$ & $\begin{array}{c}1994 / \\
95\end{array}$ & $\begin{array}{c}1995 / \\
96\end{array}$ & $\begin{array}{c}1999 / \\
00\end{array}$ & $\begin{array}{c}2005 / \\
06\end{array}$ & $\begin{array}{c}2009 / \\
10\end{array}$ & $\begin{array}{c}2014 / \\
15\end{array}$ & \begin{tabular}{|c|}
$2015 /$ \\
16
\end{tabular} & $\begin{array}{c}2016 / \\
17\end{array}$ \\
\hline $\begin{array}{l}\text { Number of pupils in the } \\
\text { country (thousands) }\end{array}$ & 525.0 & 524.0 & 520.7 & 576.1 & 519.5 & 440.5 & 344.7 & 335.2 & 330.9 \\
\hline $\begin{array}{l}\text { Number of pupils in } \\
\text { Lithuanian-language } \\
\text { schools (thousands) }\end{array}$ & 414.3 & n.d. & 447.3 & 509.9 & 475.9 & 408.1 & 317.7 & 308.4 & 304.0 \\
\hline $\begin{array}{l}\text { Number of pupils in } \\
\text { Polish-language schools } \\
\text { (thousands) }\end{array}$ & 11.4 & 16.6 & 17.9 & 21.8 & 18.4 & 14.2 & 11.6 & 11.4 & 11.3 \\
\hline $\begin{array}{l}\text { Number of pupils in Rus- } \\
\text { sian-language schools } \\
\text { (thousands) }\end{array}$ & 76.0 & n.d. & 55.4 & 44.2 & 25.0 & 17.6 & 14.4 & 14.4 & 14.5 \\
\hline $\begin{array}{l}\text { Proportion of pupils in } \\
\text { Lithuanian-language } \\
\text { schools (\%) }\end{array}$ & 82.6 & n.d. & 85.9 & 88.5 & 91.6 & 92.7 & 92.2 & 92.0 & 91.9 \\
\hline $\begin{array}{l}\text { Proportion of pupils in } \\
\text { Polish-language schools } \\
(\%)\end{array}$ & 2.3 & 3.3 & 3.5 & 3.8 & 3.5 & 3.2 & 3.4 & 3.4 & 3.4 \\
\hline $\begin{array}{l}\text { Proportion of pupils } \\
\text { in Russian-language } \\
\text { schools (\%) }\end{array}$ & 15.1 & n.d. & 10.6 & 7.7 & 4.8 & 4.0 & 4.2 & 4.3 & 4.4 \\
\hline $\begin{array}{l}\text { Number of Polish-lan- } \\
\text { guage schools }\end{array}$ & 44 & 56 & 55 & 73 & 65 & 63 & 54 & 52 & 52 \\
\hline $\begin{array}{l}\text { Number of bachelor's } \\
\text { degree students }\end{array}$ & n.d. & 45,183 & 45,487 & 63,986 & 141,771 & 144,301 & 98,852 & 93,524 & 87,797 \\
\hline $\begin{array}{l}\text { Number of students of } \\
\text { Polish origin }\end{array}$ & n.d. & 1,049 & 971 & 1,742 & n.d. & n.d. & n.d. & n.d. & n.d. \\
\hline $\begin{array}{l}\text { Proportion of students of } \\
\text { Polish origin to the total } \\
\text { number of students in } \\
\text { Lithuania (\%) }\end{array}$ & n.d. & 2.3 & 2.1 & 2.7 & n.d. & n.d. & n.d. & n.d. & n.d. \\
\hline
\end{tabular}

Source: (Lietuvos moksleivija, 1995); (Švietimas 2000, 2000); (Švietimas 2005, 2006); (Švietimas 2010, 2011); (Švietimas 2015, 2016); (Švietimas 2016, 2017).

schools - from 76 thousand in the school year 1990/91 to 14.5 thousand in 2016/17, which corresponds to a decrease of $80.92 \%$. However, it should be noted that the number of Russian-language schoolchildren in the years 2014-2017 has been slowly increasing. 


\section{INDICATOR OF HIGHER EDUCATION OF POLISH MINORITY IN LITHUANIA AND LEVEL OF ACCESSION FOR HIGHER STUDIES OF GRADUATES OF POLISH SCHOOLS}

According to the last six population censuses in Lithuania (1959, 1970, 1979, 1989, 2001, and 2011), the Polish minority in Lithuania had the lowest rate of higher education in comparison with other minorities (Table 4).

In the post-war period, between 1945 and 1989, such a low rate of higher education for the Polish minority in Lithuania can be explained by the large loss of people with higher education (the intelligentsia) resulting from the first and second post-war repatriations and a small number of Poles studying at Lithuanian universities, what ultimately did not allow to achieve the level of the national indicator of higher education. In the period 1990-2017, according to incomplete data, the share of Polish youth studying at Lithuanian universities was insufficient, ranging from $2.1 \%$ to $2.7 \%$ - such numbers could not guarantee the level of higher education equal to the national indicator.

Table 4. Higher education rate of the largest national minorities in Lithuania (number per 1000 inhabitants aged above 10)

\begin{tabular}{|l|c|c|c|c|c|c|}
\hline \multicolumn{1}{|c|}{ Nationality/Census } & 1959 & 1970 & 1979 & 1989 & 2001 & 2011 \\
\hline $\begin{array}{l}\text { National average (number per } \\
\mathbf{1 0 0 0} \text { inhabitants aged above 10) }\end{array}$ & $\mathbf{1 6}$ & $\mathbf{3 5}$ & $\mathbf{6 1}$ & $\mathbf{9 7}$ & $\mathbf{1 2 6}$ & $\mathbf{2 1 2}$ \\
\hline Lithuanians & 14 & 33 & 74 & 109 & 128 & 216 \\
\hline Poles & $\mathbf{4}$ & $\mathbf{9}$ & $\mathbf{2 8}$ & $\mathbf{5 0}$ & $\mathbf{6 3}$ & $\mathbf{1 3 8}$ \\
\hline Russians & 32 & 56 & 118 & 172 & 159 & 246 \\
\hline Belarusians & 26 & 40 & 77 & 118 & 112 & 174 \\
\hline Ukrainians & 58 & 83 & 153 & 207 & 203 & 283 \\
\hline Jews & 111 & 174 & 326 & 385 & 385 & 501 \\
\hline Roma & & - & - & - & - & 16 \\
\hline
\end{tabular}

Source: (Lietuvos TSR, 1973); (Gyventojai pagal, 2002); (Gyventojai pagal, 2012).

In the second half of the first decade of the twentieth century, in Lithuania, there was a discussion held on the introduction of free market mechanisms in the higher education system. In 2009, the system of financing higher education was changed by introducing a new solution - a 'student basket' (Wołkonowski, 2015). The meaning of this model was basically 'money follows a student' - the 'student basket' contained all the costs of studies (remuneration of lecturers and administrative and technical employees, research, maintenance of material base, etc.) related to studies for one student of a particular field of study over a one-year 
period. The number of 'baskets' was set by the Lithuanian government and it fluctuated about $47 \%$ of the number of school graduates, which is why a ranking list was also introduced for candidates applying for a 'student basket', which provided free studies. The grades of matura examinations at the state level decided which of the pupils received a 'student basket' (according to the ranking list). The candidate who was on the 'student basket' list was provided with free higher education, while the candidate who did not receive the 'student basket' could only apply for places not funded by the state - the tuition fee of such studies was practically equal to the 'student basket'. To examine this situation, let us first consider the trend in the number of 'student baskets' - Table 5.

Table 5. The number of pupils, graduates and students in 2010-2017 in Lithuania

\begin{tabular}{|l|c|c|c|c|c|c|c|c|}
\hline \multicolumn{1}{|c|}{ Indicator/Year } & 2010 & 2011 & 2012 & 2013 & 2014 & 2015 & 2016 & 2017 \\
\hline $\begin{array}{l}\text { Number of pupils } \\
\text { in the country }\end{array}$ & 440,504 & 415,873 & 392,922 & 373,874 & 357,530 & 344,721 & 335,202 & 330,869 \\
\hline $\begin{array}{l}\text { Number of } \\
\text { graduates in the } \\
\text { country }\end{array}$ & 40,710 & 40,544 & 36,755 & 33,130 & 31,807 & 30,659 & 27,453 & 26,459 \\
\hline $\begin{array}{l}\text { Number of } \\
\text { students in the } \\
\text { country }\end{array}$ & 201,005 & 186,861 & 174,823 & 159,465 & 148,473 & 140,357 & 133,296 & 125,702 \\
\hline $\begin{array}{l}\text { Number of pupils } \\
\text { in Polish-language } \\
\text { schools }\end{array}$ & 14,170 & 13,393 & 12,895 & 12,265 & 11,884 & 11,563 & 11,418 & 11,329 \\
\hline $\begin{array}{l}\text { Number of gradu- } \\
\text { ates of Polish-lan- } \\
\text { guage schools }\end{array}$ & 1,273 & 1,212 & 1,152 & 1,008 & 1,066 & 916 & 876 & 850 \\
\hline
\end{tabular}

Source: Lithuanian Statistics Department, General school pupils, University students, https://osp. stat.gov.It/statistiniu-rodikliu-analize\#/ (accessed: November 28, 2017).

According to the data in Table 5, in 2010-2017 the number of pupils and school graduates in Lithuania decreased rapidly, which is why the number of 'student baskets' decreased as well. The number of 'baskets' and their number in the particular fields of study allowed the state to correct the flood of students, granting a large number of 'baskets' to the studies important for the development of the country's economy, which increased the number of state-funded student places in such study programmes (Putinaitė, 2014; Wołkonowski, 2009, 2015). In this way, a liberal free-market mechanism of higher education was introduced in Lithuania - a student who received a 'student basket' chose the universities where to study - according to the principle 'money follows the student'. 
The next table, Table 6, presents the average national level of the 'student basket' indicator for national graduates and graduates of Polish schools. As we can see from these data, the number of 'baskets' granted to Polish schools' graduates has always been lower than the national level and fluctuated between 10.5 percentage points (hereafter p.p.) in 2010, to 26.5 p.p. in 2017 and the difference has tended to rise, which is a threat.

Table 6. The average national level and the average level of Polish-language education in Lithuania in 2010-2017 according to the 'student baskets' granted

\begin{tabular}{|l|c|c|c|c|c|c|c|c|c|}
\hline \multicolumn{1}{|c|}{ Indicator/Year } & 2010 & 2011 & 2012 & 2013 & 2014 & 2015 & 2016 & 2017 & vverage \\
\hline $\begin{array}{l}\text { Number of 'student } \\
\text { baskets' }\end{array}$ & 18,844 & 18,845 & 17,199 & 14,912 & 14,450 & 14,076 & 13,749 & 14,476 & 15,819 \\
\hline $\begin{array}{l}\text { Number of gradu- } \\
\text { ates in the country }\end{array}$ & 40,710 & 40,544 & 36,755 & 33,130 & 31,807 & 30,659 & 27,453 & 26,459 & 33,440 \\
\hline $\begin{array}{l}\text { National level of } \\
\text { the year }\end{array}$ & $\mathbf{4 6 , 3 \%}$ & $\mathbf{4 6 , 5 \%}$ & $\mathbf{4 6 , 8}$ & $\mathbf{4 5 , 0} \%$ & $\mathbf{4 5 , 4 \%}$ & $\mathbf{4 5 , 9 \%}$ & $\mathbf{5 0 , 1 \%}$ & $\mathbf{5 4 , 7 \%}$ & $\mathbf{4 7 , 3 1 \%}$ \\
\hline $\begin{array}{l}\text { Number of 'student } \\
\text { baskets' granted to } \\
\text { graduates of Polish } \\
\text { schools in Lithuania }\end{array}$ & 459 & 432 & 367 & 295 & 357 & 257 & 242 & 239 & 331 \\
\hline $\begin{array}{l}\text { Number of } \\
\text { graduates of Polish } \\
\text { schools }\end{array}$ & 1,273 & 1,212 & 1,152 & 1,008 & 1,066 & 916 & 876 & 848 & 1,044 \\
\hline $\begin{array}{l}\text { Level of Polish } \\
\text { schools according } \\
\text { to 'student basket' } \\
\text { criteria in Lithua- } \\
\text { nia (of the year) }\end{array}$ & $\mathbf{3 5 , 8 \%}$ & $\mathbf{3 5 , 3 \%}$ & $\mathbf{3 1 , 7 \%}$ & $\mathbf{2 9 , 3 \%}$ & $\mathbf{3 3 , 5 \%}$ & $\mathbf{2 8 , 1 \%}$ & $\mathbf{2 7 , 6 \%}$ & $\mathbf{2 8 , 2 \%}$ & $\mathbf{3 1 , 7 1 \%}$ \\
\hline $\begin{array}{l}\text { The number of } \\
\text { scholarships of the } \\
\text { Polish government* }\end{array}$ & $\mathbf{4 0}$ & $\mathbf{4 0}$ & $\mathbf{4 0}$ & $\mathbf{4 0}$ & $\mathbf{4 0}$ & $\mathbf{4 0}$ & $\mathbf{4 0}$ & $\mathbf{4 0}$ & $\mathbf{4 0}$ \\
\hline $\begin{array}{l}\text { Level of Polish } \\
\text { schools according } \\
\text { to 'student basket' } \\
\text { criteria and schol- } \\
\text { arships of the } \\
\text { Polish government }\end{array}$ & $\mathbf{3 9 , 2 \%}$ & $\mathbf{3 8 , 9 \%}$ & $\mathbf{3 5 , 3 \%}$ & $\mathbf{3 3 , 2 \%}$ & $\mathbf{3 7 , 2 \%}$ & $\mathbf{3 2 , 4 \%}$ & $\mathbf{3 2 , 2 \%}$ & $\mathbf{3 2 , 8 \%}$ & $\mathbf{3 5 , 5 4 \%}$ \\
\hline
\end{tabular}

* - preliminary data on scholarships awarded by the Government of the Republic of Poland to study in Poland. Source: Ministry of Education and Science of the Republic of Lithuania, www.tar.lt; Lithuanian Statistics Department, General school pupils, University students, https://osp.stat.gov. It/statistiniu-rodikliu-analize\#/ (accessed: November 28, 2017), LAMA BPO (calculations made by the National Recruitment Commission on the number of 'student baskets' granted to school graduates from Polish schools in Lithuania) (accessed: November 25, 2017). 
An important factor is that a number of graduates from Polish secondary schools and gymnasiums are granted scholarships by the Polish Government to study in Poland, thus they do not apply for a 'student basket' in Lithuania. This aspect was taken into account in the last two rows of Table 6 - as we can see the difference in levels has changed - from 7.6 p.p. in 2011 to 21.9 p.p. in 2017. Table 7 presents data on the share and number of 'student baskets' granted to school graduates from 40 Polish schools compared to the national average.

Table 7. Share of 'student baskets' of Polish schools' graduates in Lithuania compared to the national average in 2010-2017 (the upper half of a ranking list) (\%)

\begin{tabular}{|c|c|c|c|c|c|c|c|c|c|c|}
\hline No. & $\begin{array}{l}\text { Name of the school or } \\
\text { gymnasium/Year }\end{array}$ & 2010 & 2011 & 2012 & 2013 & 2014 & 2015 & 2016 & 2017 & $\begin{array}{c}\text { Average } \\
\text { 2010-2017 }\end{array}$ \\
\hline 1 & $\begin{array}{l}\text { J.I. Kraszewski Gymn. in } \\
\text { Vilnius }\end{array}$ & 58,7 & 50,7 & 45,7 & 58,7 & 54,5 & 43,8 & 43,2 & 55,0 & 51,3 \\
\hline 2 & $\begin{array}{l}\text { K. Parczewski Gymn. in } \\
\text { Nemenčinė }\end{array}$ & 50,9 & 40,0 & 43,5 & 50,0 & 50,0 & 42,9 & 55,6 & 45,5 & 46,9 \\
\hline 3 & $\begin{array}{l}\text { H. Sienkiewicz Gymn. in } \\
\text { Lentvaris }\end{array}$ & 20,0 & 60,0 & 39,1 & 62,5 & 43,5 & 78,9 & 31,8 & 40,0 & 45,2 \\
\hline 4 & $\begin{array}{l}\text { John Paul II Gymn. in } \\
\text { Vilnius }\end{array}$ & 43,2 & 45,4 & 43,3 & 31,8 & 31,4 & 39,8 & 37,2 & 37,4 & 38,9 \\
\hline 5 & $\begin{array}{l}\text { A. Mickiewicz Gymn. in } \\
\text { Vilnius }\end{array}$ & 35,7 & 45,0 & 49,0 & 39,4 & 36,1 & 31,2 & 32,6 & 35,1 & 38,1 \\
\hline 6 & $\begin{array}{l}\text { V. Syrokomla Gymn. in } \\
\text { Vilnius }\end{array}$ & 37,4 & 51,1 & 29,2 & 32,5 & 43,0 & 34,2 & 30,5 & 40,2 & 37,8 \\
\hline 7 & $\begin{array}{l}\text { S. Konarski Secondary } \\
\text { School in Vilnius }\end{array}$ & 42,4 & 30,8 & 40,7 & 43,2 & 22,4 & 27,9 & $\mathrm{nmc}$ & $\mathrm{nmc}$ & 37,2 \\
\hline 8 & J. Lelewel Gymn. in Vilnius & 27,6 & 48,4 & 39,1 & 22,7 & 37,9 & 41,2 & 34,8 & 33,3 & 35,9 \\
\hline 9 & Gymn. in Mickunai & 22,7 & 30,4 & 41,7 & 23,1 & 78,6 & 53,8 & 50,0 & 15,0 & 35,6 \\
\hline 10 & Gymn. in Grigiškès & 21,4 & 41,7 & 28,6 & 40,0 & 62,5 & 0,0 & $\mathrm{nmc}$ & $\mathrm{nmc}$ & 35,1 \\
\hline 11 & $\begin{array}{l}\text { Secondary School in } \\
\text { Čekoniškès }\end{array}$ & 40,0 & 50,0 & $\mathrm{nmc}$ & 18,2 & 42,9 & 14,3 & $\mathrm{nmc}$ & $\mathrm{nmc}$ & 34,0 \\
\hline 12 & Gymn. in Avižieniai & 25,0 & 35,7 & 66,7 & 14,3 & 75,0 & 22,2 & 7,7 & 21,4 & 33,8 \\
\hline 13 & $\begin{array}{l}\text { E. Orzeszkowa Gymn. in } \\
\text { Baltoji Voké }\end{array}$ & 46,7 & 12,5 & $\mathrm{nmc}$ & 20,0 & 46,2 & 28,6 & 22,2 & 28,6 & 33,3 \\
\hline 14 & $\begin{array}{l}\text { M. Baliński Gymn. in } \\
\text { Jašiūnai }\end{array}$ & 32,3 & 33,3 & 26,9 & 7,7 & 43,5 & 33,3 & 36,8 & 29,4 & 31,4 \\
\hline 15 & $\begin{array}{l}\text { St. Casimir Gymn. in } \\
\text { Medininkai }\end{array}$ & 50,0 & 30,0 & $\mathrm{nmc}$ & 26,7 & 33,3 & $\mathrm{nmc}$ & 33,3 & 0,0 & 30,9 \\
\hline 16 & $\begin{array}{l}\text { J. Śniadecki Gymn. in } \\
\text { Šalčininkai }\end{array}$ & 44,4 & 36,9 & 17,0 & 24,5 & 41,2 & 19,7 & 27,0 & 30,4 & 30,5 \\
\hline 17 & Gymn. in Rukainiai & 47,6 & 28,6 & 20,8 & 50,0 & 50,0 & 13,6 & 16,7 & 20,0 & 30,3 \\
\hline 18 & Gymn. in Trakai & 42,9 & 23,5 & 25,0 & 38,9 & 20,0 & 20,0 & 31,3 & 26,7 & 29,1 \\
\hline
\end{tabular}




\begin{tabular}{|c|l|c|c|c|c|c|c|c|c|c|}
\hline No. & $\begin{array}{l}\text { Name of the school or } \\
\text { gymnasium/Year }\end{array}$ & 2010 & 2011 & 2012 & 2013 & 2014 & 2015 & 2016 & 2017 & $\begin{array}{c}\text { Average } \\
\text { 2010-2017 }\end{array}$ \\
\hline 19 & $\begin{array}{l}\text { T. Konwicki Gymn. in } \\
\text { Buivydžiai }\end{array}$ & 36,0 & 37,5 & 29,4 & 28,0 & 6,3 & 27,3 & 31,3 & 25,0 & 28,2 \\
\hline 20 & $\begin{array}{l}\text { S. Batory Gymn. in } \\
\text { Lavoriškès }\end{array}$ & 39,1 & $\mathbf{5 0 , 0}$ & 17,6 & 30,0 & 13,3 & 6,7 & $\mathrm{nmc}$ & $\mathbf{3 3 , 3}$ & 28,2 \\
\hline $21-41$ & $\ldots$ & & & & & & & & $\mathbf{3 1 , 6}$ \\
\hline & $\begin{array}{l}\text { Total share of 'baskets' } \\
\text { - Polish schools }\end{array}$ & $\mathbf{3 5 , 8}$ & $\mathbf{3 5 , 3}$ & $\mathbf{3 1 , 7}$ & $\mathbf{2 9 , 3}$ & $\mathbf{3 3 , 5}$ & $\mathbf{2 8 , 1}$ & $\mathbf{2 7 , 6}$ & $\mathbf{2 8 , 2}$ & $\mathbf{3 1 , 6}$ \\
\hline
\end{tabular}

Gymn. - Gymnasium; nmc - no matura class that year. Source: LAMA BPO (calculations made by the National Recruitment Commission on the number of 'student baskets' granted to school graduates from Polish schools in Lithuania) (accessed: November 25, 2017).

Analysing Tables 7 and 8, we can see that only one Polish gymnasium, J.I. Kraszewski, according to the criterion of the average share of the 'student basket', had a higher level of $51.3 \%$, comparing to the national average $-47.31 \%$, in the analysed period between 2010 and 2017. In particular years only individual gymnasiums exceeded the national average: in 2010 and in 2011 there were 6 gymnasiums; in 2012 - 2 gymnasiums; in 2013 - 5 gymnasiums; in $2014-7$ gymnasiums; in 2015 - 2 gymnasiums; in 2016 - 2 gymnasiums; in 2017 - 1 gymnasium. According to Tables 7 and 8, in the period between 2010 and 2017, 8,378 pupils graduated from Polish schools in Lithuania and 2,648 of them received a 'student basket', which constituted $31.6 \%$ of all Polish gymnasiums' students. With the national average (47.3\%), the number of 'student baskets' is 3,963, which results in a shortage of 1,315 'baskets' for graduates of Polish gymnasiums.

On the other hand, one should note the negative actions of the Lithuanian authorities during the period under consideration, which severely discriminated against Polish schools in Lithuania and the pupils of these schools. The following activities of the Lithuanian authorities should be mentioned: 1 . suspension of publishing textbooks in Polish for upper classes in 1994; 2. deletion of the exam of Polish Language and Literature as the mother tongue from the list of compulsory matura examinations in 1998; 3. adoption of the amendment to the Education Act of the Republic of Lithuania (in 2011) requiring the introduction of a unified matura examination of the state language (Lithuanian) in 2013 without a transitional period. Strong protests of Polish schools and social organizations were lodged against such moves; however, they were neglected by the Lithuanian authorities. One of the examples of the protests was the petition with 60131 signatures against the amendment to the Education Act, requiring the unification of the matura exam in a state language without a transitional period (Kwiatkowski, 2015). The decision had a very negative impact on the level of admission of graduates from Polish 
Table 8. The number of 'student baskets' granted to school graduates from Polish schools in Lithuania (the upper half) and the number of school graduates in 2010-2017

\begin{tabular}{|c|c|c|c|c|c|c|c|c|c|c|c|c|c|c|c|c|c|c|c|}
\hline \multirow[b]{2}{*}{ No. } & \multirow{2}{*}{\begin{tabular}{|l|} 
Name of the school or gymnasium/Year \\
$\begin{array}{l}\text { Number of 'baskets' and number of } \\
\text { graduates }\end{array}$
\end{tabular}} & \multicolumn{2}{|c|}{2010} & \multicolumn{2}{|c|}{2011} & \multicolumn{2}{|c|}{2012} & \multicolumn{2}{|c|}{2013} & \multicolumn{2}{|c|}{2014} & \multicolumn{2}{|c|}{2015} & \multicolumn{2}{|c|}{2016} & \multicolumn{2}{|c|}{2017} & \multicolumn{2}{|c|}{ Total } \\
\hline & & NB & NG & NB & NG & NB & $N G$ & NB & NG & NB & $N G$ & NB & NG & NB & $N G$ & NB & NG & NB & $N G$ \\
\hline 1 & J.I. Kraszewski Gymn. in Vilnius & 37 & 63 & 35 & 69 & 32 & 70 & 27 & 46 & 30 & 55 & 21 & 48 & 19 & 44 & 22 & 40 & 223 & 435 \\
\hline 3 & H. Sienkiewicz Gymn. in Lentvaris & 6 & 30 & 15 & 25 & 9 & 23 & 10 & 16 & 10 & 23 & 15 & 19 & 7 & 22 & 4 & 10 & 76 & 168 \\
\hline 4 & John Paul II Gymn. in Vilnius & 60 & 139 & 49 & 108 & 55 & 127 & 35 & 110 & 37 & 118 & 37 & 93 & 29 & 78 & 34 & 91 & 336 & 864 \\
\hline 7 & S. Konarski Secondary School in Vilnius & 25 & 59 & 20 & 65 & 22 & 54 & 19 & 44 & 13 & 58 & 12 & 43 & 6 & 0 & 3 & 0 & 120 & 323 \\
\hline 8 & J. Lelewel Gymn. in Vilnius & 8 & 29 & 15 & 31 & 9 & 23 & 5 & 22 & 11 & 29 & 7 & 17 & 8 & 23 & 7 & 21 & 70 & 195 \\
\hline 9 & Gymn. in Mickunai & 5 & 22 & 7 & 23 & 5 & 12 & 6 & 26 & 11 & 14 & 7 & 13 & 8 & 16 & 3 & 20 & 52 & 146 \\
\hline 10 & Gymn. in Grigiškès & 3 & 14 & 5 & 12 & 2 & 7 & 4 & 10 & 5 & 8 & 0 & 6 & 0 & 0 & 1 & 0 & 20 & 57 \\
\hline 11 & Secondary School in Čekoniškès & 4 & 10 & 6 & 12 & 0 & 0 & 2 & 11 & 3 & 7 & 1 & 7 & 0 & 0 & 0 & 0 & 16 & 47 \\
\hline 12 & Gymn. in Avižieniai & 4 & 16 & 10 & 28 & 12 & 18 & 2 & 14 & 9 & 12 & 4 & 18 & 1 & 13 & 3 & 14 & 45 & 133 \\
\hline 16 & J. Śniadecki Gymn. in Šalčininkai & 28 & 63 & 24 & 65 & 9 & 53 & 13 & 53 & 21 & 51 & 12 & 61 & 10 & 37 & 14 & 46 & 131 & 429 \\
\hline 17 & Gymn. in Rukainiai & 10 & 21 & 6 & 21 & 5 & 24 & 5 & 10 & 10 & 20 & 3 & 22 & 2 & 12 & 3 & 15 & 44 & 145 \\
\hline 18 & Gymn. in Trakai & 9 & 21 & 4 & 17 & 6 & 24 & 7 & 18 & 3 & 15 & 3 & 15 & 5 & 16 & 4 & 15 & 41 & 141 \\
\hline 19 & T. Konwicki Gymn. in Buivydžiai & 9 & 25 & 6 & 16 & 5 & 17 & 7 & 25 & 1 & 16 & 3 & 11 & 5 & 16 & 4 & 16 & 40 & 142 \\
\hline 20 & S. Batory Gymn. in Lavoriškès & 9 & 23 & 7 & 14 & 3 & 17 & 3 & 10 & 2 & 15 & 1 & 15 & 1 & 0 & 3 & 9 & 29 & 103 \\
\hline$\ldots$ & $\ldots$ & & & & & & & & & & & & & & & & & & \\
\hline & Total in that year: & \begin{tabular}{|l|l}
459 & 1 \\
\end{tabular} & 1,283 & 432 & 1,224 & 367 & 1,157 & 295 & 1,008 & 357 & 1,066 & 257 & 916 & 242 & 876 & 239 & 848 & 2,648 & 8,351 \\
\hline
\end{tabular}


schools to higher studies in Lithuania, because the grade in this subject is very important while calculating the student's ranking to gain a 'student basket', which in many cases prevented the candidate from Polish schools in Lithuania from receiving 'student basket'. Thus, such actions of the Lithuanian authorities made a negative impact on the level of the higher education rate of the Polish minority in Lithuania.

\section{CONCLUSIONS}

Polish-language education in Lithuania is a unique phenomenon on a European scale. The network of public schools with the Polish language of instruction is aimed at educating the young generation of the Polish minority in Lithuania. Polish-language education in Lithuania has its deep-rooted traditions, numerous achievements, but also problems. The numerous network of Polish schools in Lithuania is on the one hand a certain phenomenon on a European scale, on the other hand, it raises concerns and fears of the Lithuanian authorities about the national character of state education. Throughout the post-war period, the share of Polish-language education in Lithuania was within 3-3,5\%, which, with 6-7\% of Polish population in Lithuania, meant that half of all Polish children learned in a Polish school in Lithuania.

In the period 1945-1955, the communist authorities of Lithuania took active steps aimed at lithuanization the Polish-language education in the Vilnius region, which was received with the incorporation of these areas to Lithuania by the Soviet authorities after the Second World War. Despite the large outflow of the intelligentsia from the Vilnius region during the two post-war repatriations, Poles in Lithuania were able to defend their education - desperate resistance of parents and complaints to the communist authorities in Vilnius and Moscow in support for schools with Polish language of instructions achieved the desired results: the Soviet authorities, in accordance with the principle 'divide and rule', agreed to the functioning of schools with the Polish language of instruction in Lithuania, as Lithuanian schools also functioned here, and ordered the communist authorities of Lithuania to provide education for teaching staff for these schools. However, in the late 1950s and in the following decades of the $20^{\text {th }}$ century, the communist authorities of Lithuania took steps towards russification of Polish education. Because of these activities, the number of pupils in Polish schools began to decrease, while in Russian schools the number of pupils increased significantly. During this period, there was a noticeable russification of the Polish minority in Lithuania. The mass 
departure of the Polish intelligentsia from the Vilnius region during the first and second post-war repatriations caused major changes in the professional structure of the Polish minority in Lithuania, which was revealed by the population censuses of 1959 and 1970 - the Polish minority in Lithuania ranked last in accordance with the higher education rate per 1,000 inhabitants - the minority lacked the intelligentsia. In the following decades, the proportion of the young generation of the Polish minority at universities was low - it was due to the weakening level of Polish education in Lithuania and its strong russification.

After 1990, with the regaining of the independence of Lithuania, there was a revival of Polish-language education in Lithuania - the number of pupils increased from 10 thousand in 1989 to 21.8 thousand in 2000, while the number of Polish schools increased from 44 to 73 during this period. However, in the following years this dynamic development was stopped due to the drastic demographic decline (as a result of the lack of pro-family policy) and negative decisions of the Lithuanian authorities. The number of children in Polish schools decreased to 11.3 thousand in 2017, while the number of schools dropped to 52.

In the period between 2010 and 2017, 8,351 pupils graduated from Polish schools in Lithuania, 2,648 of whom received a 'student basket', which provided them with free higher education at Lithuanian universities. This constituted 31.6\% of the total number of high school graduates, with the national average of $47.3 \%$ in the analysed period. The difference in levels is 15.7 p.p. - it is a shortage of 1,315 'student baskets' for graduates of Polish schools. The proportion of school graduates with a 'student basket' from Polish schools in Lithuania has a declining trend: from 35.8\% (compared to national average of 46.3\%) in 2010 to $28.2 \%$ in 2017 (national average - 54.7\%). Out of the 40 Polish gymnasiums and secondary schools studied, only one, namely J.I. Kraszewski Gymnasium, has a better result (51.3\%) for the years 2010-2017 than the national average in this period (47.3\%). The next two gymnasiums (K. Parczewski Gymnasium in Nemenčinè and H. Sienkiewicz Gymnasium in Lentvaris) hold slightly lower position than the national average by 0.4 p.p. and 2.1 p.p. respectively - this difference is very small. Other Polish schools have a lower rate than the national average. The declining share of the 'student baskets' among Polish graduates overlap with the period of introducing a unified examination in the state Lithuanian language in 2013. With the declining proportion of the 'student baskets' among graduates of Polish schools, it will be difficult for the Polish minority to reach the national average level of higher education in Lithuania, which has been more than twice lower than the national average for the entire period, and 1.54 times - during the last population census of 2011. The solution to this problem may be achieved by changing the 
attitude of the Lithuanian authorities to Polish education in Lithuania and reaching the average national level by these schools according to the number of 'student baskets' granted. The branch of the University of Białystok in Vilnius (Faculty of Economics and Information Technology in Vilnius), which started its activity in 2007 and educated 620 graduates during the first 10 years of its activity, has its contribution to the improvement of the higher education index.

\section{ACKNOWLEDGMENTS}

The author expresses thanks to prof. Pranas Žiliukas, the president of LAMA BPO, for sharing data on the number of 'student baskets' granted to graduates of Polish-language gymnasiums in Lithuania in 2010-2017.

\section{References}

Gyventojai pagal išsilavinimq, gimtajq kalbq ir kalbu mokẻjimq (2002) [Residents by Education, Mother Tongue and Language]. Statistikos Departamentas, Vilnius.

Gyventojai pagal išsilavinimq ir kalbu mokèjimq, Lietuvos Respublikos 2011 metu visuotinio gyventojų ir būstų surašymo rezultatai (2012). Statistikos Departamentas, Vilnius.

Kuzborska, E. (2012). Sytuacja prawna mniejszości narodowych na Litwie w kontekście międzynarodowychiponadnarodowychstandardówichochrony. Warszawa: Wydawnictwo Sejmowe.

Kuzborska, E. (2013). Legal Situation of National Minorities in Lithuania - in the Context of International and Supranational Protection Standards. Vilnius: Artprint JSC.

Kwiatkowski, J. (2015). Na straży oświaty polskiej na Litwie. Wilno: Stowarzyszenie Nauczycieli Szkół Polskich na Litwie „Macierz Szkolna”.

Lietuvos mokymo istaigos Statistinis rinkinys (1990). Vilnius.

Lietuvos moksleivija ir studentija (1995). Statistikos departamentas prie Lietuvos Respublikos Vyriausybės, Vilnius.

Lietuvos Statistikos Metraštis 1989 metai (1990). Lietuvos Statistikos Departamentas, Vilnius.

Lietuvos Statistikos Metraštis 1990 (1991). Lietuvos Statistikos Departamentas, Vilnius, pp. 79-80.

Lietuvos Statistikos Metraštis 2002 (2002). Lietuvos Statistikos Departamentas, Vilnius.

Lietuvos TSR ekonomika ir kultūra 1967 metais (1968). Statistikos duomenų rinkinys, Centrinė statistikos valdyba prie Lietuvos TSR Ministrų Tarybos, Vilnius.

Lietuvos TSR ekonomika ir kultūra 1972 metais (1973). Statistikos Metraštis, Centrinė Statistikos Valdyba prie Lietuvos TSR Ministrų Tarybos, Vilnius.

Lietuvos TSR liaudies ūkis 1956 metais (1957). Lietuvos TSR statistikos valdyba, Vilnius.

Lietuvos TSR liaudies ūkis 1965 metais (1966). Statistinių duomenų rinkinys, Centrinė Statistikos Valdyba prie Lietuvos TSR Ministrų Tarybos, Vilnius.

Lietuvos TSR liaudies ūkis 1978 metais (1979). Statistikos metraštis, Lietuvos TSR statistikos valdyba, Vilnius.

Lietuvos TSR liaudies ūkis 1981 metais (1982). Statistikos Metraštis, Lietuvos TSR Centrinė Statistikos Valdyba, Vilnius. 
Mikłaszewicz, I. (2016). Niektóre aspekty radzieckiej polityki narodowościowej na Litwie w latach 1944-1990. Rocznik Stowarzyszenia Naukowców Polaków Litwy, 16, pp. 82-90.

Putinaitė, N. (2014). Mokslo ir studijų pertvarkos Lietuvoje atvejis. In: P.V. Subačius (Ed.), Reforma Lietuvoje (pp. 13-105). Vilnius: Alma littera.

Sienkiewicz, J. (Ed.) (2009). Szkoły Polskie w Republice Litewskiej. Wilno: Stowarzyszenie Nauczycieli Szkół Polskich na Litwie „Macierz Szkolna”, Scripta manent.

Srebrakowski, A. (2002). Polacy w Litewskiej SRR 1944-1989. Toruń: Wydawnictwo Adam Marszałek.

Švietimas 2000 (2000). Statistikos departamentas prie Lietuvos Respublikos Vyriausybės, Vilnius.

Švietimas 2005 (2006). Statistikos departamentas prie Lietuvos Respublikos Vyriausybės, Vilnius.

Švietimas 2010 (2011). Statistikos departamentas prie Lietuvos Respublikos Vyriausybės, Vilnius.

Švietimas 2015 (2016). Statistikos departamentas prie Lietuvos Respublikos Vyriausybès, Vilnius.

Švietimas 2016 (2017). Statistikos departamentas prie Lietuvos Respublikos Vyriausybės, Vilnius.

Wołkonowski, J. (2009). Aspekt polityczny reformy nauki i szkolnictwa wyższego na Litwie w latach 2007-2009. In: E. Kużelewska, A. Bartnicki (Eds.), Zachód w globalnej i regionalnej polityce międzynarodowej: teoria i praktyka (pp. 143-157). Toruń: Wydawnictwo Adam Marszałek.

Wołkonowski, J. (2015). Szkolnictwo wyższe na Litwie w okresie 1989-2014 - od interwencjonizmu do liberalizmu. Optimum. Studia Ekonomiczne, 3, pp. 180-192. 